\title{
A Two-Step Model that Predicts $\alpha$-Amylase Activity in Solvents with High and Low Dielectric Constants
}

\author{
Arshad Khan* \\ Department of Chemistry, Pennsylvania State University, USA \\ *Corresponding author: Arshad Khan, Department of Chemistry, Pennsylvania State University, USA
}

\section{ARTICLE INFO}

Received: 慧 June 18, 2019

Published: June 24, 2019

Citation: Arshad Khan. A Two-Step Model that Predicts $\alpha$-Amylase Activity in Solvents with High and Low Dielectric Constants. Biomed J Sci \& Tech Res 19(1)-2019. BJSTR. MS.ID.003251.

\begin{abstract}
Some years ago, the present author put forward a two-step inactivation model for $\alpha$-amylase (enzyme). The effect of heat and various substances on the enzyme activity have already been studied experimentally in aqueous solutions and confirmed the theoretical predictions of the model. In this paper we describe the effect of solvents with varied dielectric constants on the enzyme activity.
\end{abstract}

\section{Introduction}

$\alpha$-Amylase is a metallo-enzyme that contains at least $1 \mathrm{~mol}$ of calcium ion [1-4] per mole of protein. The strength of the binding of calcium ions to the protein varies according to the source of the enzyme, and for all $\alpha$-amylases the presence of calcium ions increases the stability of the enzyme toward denaturation by heat, acid, or urea [2]. Irrespective of the source, this enzyme causes a rapid fragmentation of starch molecules into sugars [5-7] and undergoes inactivation reaction initiated by an initial dissociation of $\mathrm{Ca}^{2+}$ ions followed by denaturation by heat [8-10].

\section{Theory of Inactivation of $\alpha$-Amylase}

The first reversible stage (eq 1) involves a forward reaction that forms an inactive apoenzyme, $\mathrm{E}^{2-}$, from the active enzyme, $\mathrm{CaE}$, with a rate constant of $\mathrm{k}_{1}$ and a reverse reactivation reaction involving the combination of $\mathrm{E}^{2-}$ with calcium ions with a rate constant of $\mathrm{k}_{-1}$. The second irreversible stage (eq 2) of reaction forms a denatured form of the enzyme, $\mathrm{EI}^{2-}$, from $\mathrm{E}^{2-}$ with a rate constant of $\mathrm{k}_{2}$. The reversibly inactivated form, $\mathrm{E}^{2-}$, can be quickly transformed into the active form, $\mathrm{CaE}$, by adding calcium ions. On the other hand, the $\mathrm{EI}^{2-}$ is the denatured form of the enzyme that cannot be reactivated by adding calcium ions.

$$
\begin{aligned}
& C a E \underset{k_{-1}}{\stackrel{k_{1}}{\rightleftharpoons}} \mathrm{Ca}^{2+}+E^{2-} \\
& E^{2-} \stackrel{k_{2}}{\longrightarrow} E I^{2-} .
\end{aligned}
$$

On the basis of inactivation steps 1 and 2, the following equations can be derived:

$$
\begin{array}{r}
X D=1-e^{-k_{3} t} \\
\text { Where, } k_{3}=\frac{k_{1} k_{2}}{k_{-1}\left[\mathrm{Ca}^{2+}\right]+k_{2}} \ldots
\end{array}
$$

The expression XD (eq 3) gives the fraction of enzyme inactivated at a time $t$, after the inactivation process begins, and $\mathrm{k}_{3}$, given by equation 4 , is a function of calcium ion concentration and temperature. From the expression 3 one can readily obtain the value of percent active enzyme as follows:

$$
\text { Percent Active Enzyme }=(1-X D) 100=100 e^{-k_{3} t}
$$

A more detailed derivation of equation 3 (and hence, eq 5) as well as various test results can be found in references [8-10].

\section{Solvent Effect}

A polar solvent with high dielectric constant aids in dissociating ionic substances into ions and stabilizes them in the solution. Since the first stage (eq 1) of enzyme inactivation involves dissociation of metallo-enzyme ( $\mathrm{CaE}$ ) into ionic species, this process will be favored by a solvent with high dielectric constant. As the dielectric constant is reduced, the ionization step 1 , and hence, the inactivation step 1 becomes increasingly less favored, and the metallo-enzyme 
achieves a greater stability. Indeed, the experimental results show this trend. Based on the study of Calabrese, Minns and Khan [10] on enzyme inactivation in ethanol-water mixed solutions, we provide the following table of dielectric constants with the associated activity values after the 60 minutes of heat inactivation at $30{ }^{\circ} \mathrm{C}$. Dielectric constants for different ethanol-water mixed solutions were obtained from reference 11. As expected from the theory, large dielectric constant like 66 shows enzyme activity of only $12 \%$ (88\% inactivated), whereas a low dielectric constant like 37 shows activity of $95 \%$ with only $5 \%$ of the enzyme getting inactivated. Although these results were obtained for ethanol-water mixed solutions, it is expected that the same trend will be obtained for other types of solvents. So, the relationship that we presented here in Table 1 will be valuable to those who will carry out the enzyme inactivation experiments in the future involving other solvents with varied dielectric constants.

Table 1: Dielectric constants [11] and enzyme activity [10] in Ethanol-water mixed solutions at $30^{\circ} \mathrm{C}$ after 60 minutes of inactivation.

\begin{tabular}{|c|c|c|}
\hline \% Ethanol & Dielectric constant & \% Active Enzyme \\
\hline 10 & 66.26 & 12 \\
\hline 20 & 55.81 & 45 \\
\hline 30 & 47.48 & 68 \\
\hline 40 & 41.28 & 88 \\
\hline 50 & 37.21 (interpolated value) & 95 \\
\hline
\end{tabular}

\section{References}

ISSN: 2574-1241

DOI: 10.26717/BJSTR.2019.19.003251

Arshad Khan. Biomed J Sci \& Tech Res

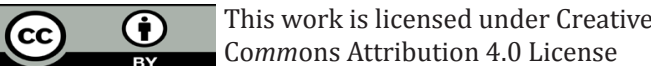

Submission Link: https://biomedres.us/submit-manuscript.php
1. Kakiuchi K, Kato S, Imanishi A, Isemura T (1964) Association and dissociation of Bacillus subtilis a-amylase. J Biochem 55: 102-109.

2. Whitaker JR (1972) In: Principles of Enzymology for the Food Sciences. New York Dekker pp. 433-467.

3. Boel E, Andrzej M Brzozowski, Zygmunt S Derewenda, Guy G Dodson, Vagn Juhl Jensen, et al. (1990) Calcium binding in a-amylases: An X-ray diffraction study at 2.1 - $\AA$ resolution of two enzymes from Aspergillus. Biochemistry 29: 6244-6249.

4. Chandel AK, Rudravaram R, Rao LV, Pogaku R, Narasu ML (2007) Industrial enzymes in bioindustrial sector development: An Indian perspective. J Comm Biotechnol 13: 283-291.

5. Manners DJ (1962) Enzymic synthesis and degradation of starch and glycogen. Adv. Carbohydr. Chem 17: 371-430.

6. Thoma JA, Spradlin JE, Dygert S (1971) The Enzymes. Boyer PD (Eds.), $3^{\text {rd }}(E d n), 5:. 115-189$.

7. Takagi T, Toda H, Isemura, $T$ (1971) Bacterial and mold amylases. In: The Enzymes Boyer PD (Eds.), 5: 235-271.

8. Lecker DN, Khan A (1996) Theoretical and experimental studies of the effects of heat, EDTA, and enzyme concentration on the inactivation rate of $\alpha$-amylase from Bacillus sp. Biotechnol Prog 12(5): 713-717.

9. Lecker DN, Khan A (1998) Model for inactivation of $\alpha$-amylase in the presence of salts: theoretical and experimental Studies. Biotechnol Prog 14: 621-625.

10. Calabrese VT, Minns JW, Khan A (2016) Suppression of $\alpha$-Amylase inactivation in the presence of Ethanol: Application of a two-step model. Biotechnology Progress 32(5): 1271-1275.

11. Morlyoshi T, Ishll T, Tamal Y, Tado M (1990) Static Dielectric Constants of Water + Ethanol and Water + 2-Methyl-2-propanol Mixtures from 0.1 to $300 \mathrm{MPa}$ at 298.15 K. J Chem Eng Data 35(1): 17-20.

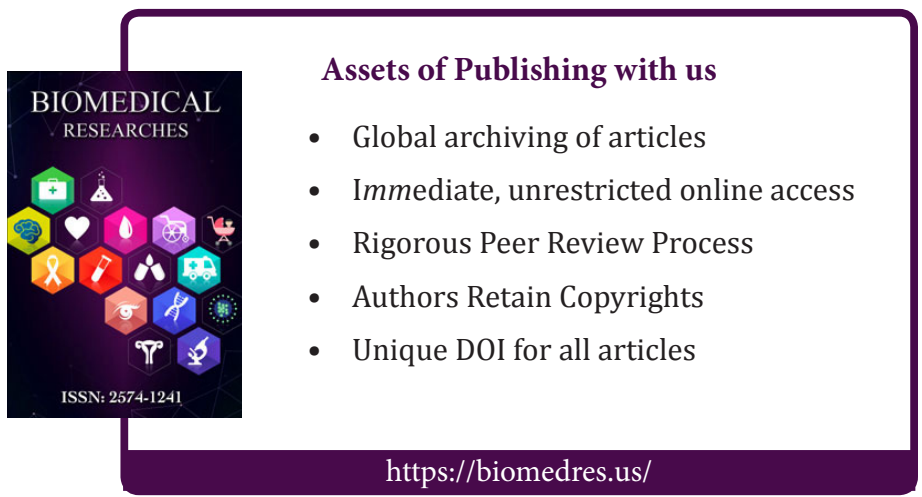

